\title{
Perineal and Abdominal Approaches in the Surgical Treatment of Rectal Prolapse: Our 10-year Clinical Experience
}

\author{
Rektal Prolapsus Cerrahi Tedavisinde Perineal ve Abdominal Yaklaşım: \\ 10 Ylllık Klinik Deneyimimiz
}

\section{(D) Ömer Başol, (D) Hüseyin Bilge, (D) Faik Veysel Akpulat, (D) Gizem Yaman, (D) Abdullah Oğuz}

Dicle University Faculty of Medicine, Department of General Surgery, Diyarbakır, Turkey

\section{Abstract}

Objective: Rectal prolapse is a rare condition characterized by protrusion of the rectum with all its layers from the anus. It is a disease that causes social and functional problems. In this study, it was aimed to investigate the abdominal and perineal approaches together with postoperative early and late results in our patients who underwent surgical treatment for rectal prolapse.

Method: The records of 39 patients who were operated on with the diagnosis of rectal prolapse between 2010 and 2020 in the Department of General Surgery, Dicle University Faculty of Medicine were evaluated retrospectively. Demographic and physical examination findings of the patients, surgical methods applied, early and late postoperative complications, recurrence and mortality rates were recorded.

Results: The most common complaints on admission to the hospital were gas control disorder, difficulty in defecating and getting wet with mucus. On physical examination, stage 1 rectal prolapse was found in $12.8 \%$ of the patients, and full-thickness prolapse was found in the other patients. The mean age of 39 patients included in the study was 36 (1488 ) years. Of the patients included in the study, 14 (35.9\%) were female and $25(64.1 \%)$ were male. Surgery was performed with an abdominal and perineal approach in $53.8 \%$ of the patients, while laparoscopy was performed in $46.2 \%$. The most frequently used abdominal surgical technique was Notaras (35.8\%). The most common perineal approach technique was Altemeier (5.1\%). Patients who underwent the perineal approach were older and had a shorter hospital stay, and it was often performed under regional anesthesia. Complications developed in the early postoperative period in $10.4 \%$ of the patients. The median hospital stay was 5 days (2-19) and the follow-up period was 13 months (9-19). Postoperative mortality did not occur in any of the patients. Hospital

\section{Öz}

Amaç: Rektal prolapsus, rektumun tüm katmanlarıyla birlikte anüsten çıkması ile karakterize nadir bir durumdur. Sosyal ve fonksiyonel sorunlara neden olan bir hastalıktır. Bu çalışmada, rektal prolapsus için laparoskopik ve açık cerrahi yöntemin postoperatif erken ve geç sonuçlarının araştıııması amaçlanmıştır.

Yöntem: Dicle Üniversitesi Tıp Fakültesi Genel Cerrahi Anabilim Dalı'nda 2010-2020 yılları arasında rektal prolapsus tanısıyla ameliyat edilen 39 hastanın kayıtları geriye dönük olarak değerlendirildi. Demografik ve fizik muayene bulguları, cerrahi yöntem, postoperatif erken ve geç komplikasyonlar, morbidite ve mortalite oranları kaydedildi.

Bulgular: Hastaneye başvuruda en sık başvuru şikayetleri gaz kontrol bozukluğu, dışkılamada güçlük ve mukusla ıslanma idi. Fizik muayenede hastaların \%12,8'inde evre 1 rektal prolapsus, diğer hastalarda tam kat prolapsus saptandı. Çalışmaya alınan 39 hastanın yaş ortalaması 36 (1488) idi. Çalışmaya alınan hastaların 14'ü $(\% 35,9)$ kadın, 25'i $(\% 64,1)$ erkekti. Hastaların \%53,8'ine açık karın cerrahisi yapılırken, \%46,8'ine laparoskopi yapıldı. En sık kullanılan abdominal cerrahi teknik Notaras (\%35,8) idi. En yaygın perineal yaklaşım tekniği Altemeier $(\% 5,1)$ idi. Perineal yaklaşım uygulanan hastalar daha yaşııdı ve hastanede kalış süreleri daha kısaydı ve sıklıkla bölgesel anestezi altında uygulanıyordu. Hastaların \%10,4'ünde erken postoperatif dönemde komplikasyon gelişti. Ortanca hastanede kalış süresi 5 gün (2-19), takip süresi 13 ay (9-19) idi. Hiçbir hastada postoperatif mortalite olmadı. Laparoskopik cerrahi uygulanan hastalarda hastanede kalış süresi anlamlı olarak daha kısaydı. Erken postoperatif komplikasyonlar ve nüks açııından istatistiksel olarak fark yoktu.

Sonuç: Rektal prolapsusu olan hastanın risk faktörleri göz önüne alındığında hem laparoskopik hem de açık cerrahi yaklaşımların sonuçları

Address for Correspondence: Hüseyin Bilge, Dicle University Faculty of Medicine, Department of General Surgery, Diyarbakır, Turkey E-mail: dr.huseyinbilge@hotmail.com ORCID: orcid.org/0000-0001-7203-2288 Received: 19.01.2021 Accepted: 10.08.2021

Cite this article as: Başol Ö, Bilge H, Akpulat FV, Yaman G, Oğuz A. Perineal and Abdominal Approaches in the Surgical Treatment of Rectal Prolapse: Our 10-year Clinical Experience. Bagcilar Med Bull 2021;6(4):355-360

${ }^{\circ}$ Copyright 2021 by the Health Sciences University Turkey, Bagcilar Training and Research Hospital Bagcilar Medical Bulletin published by Galenos Publishing House. 


\section{Abstract}

stay was significantly shorter in patients who underwent laparoscopic surgery. There was no statistical difference in terms of early postoperative complications and recurrence.

Conclusion: Although more than a hundred surgical procedures have been described to date for the treatment of rectal prolapse, the ideal treatment method is still unclear. In terms of surgical treatment, the results of abdominal or perineal approaches to be applied are similar, considering the risk factors, patient findings and surgeon's experience.

Keywords: Abdominal and perineal surgery, notaras operation, rectal prolapse

\section{Introduction}

Rectal prolapse (RP) is the protrusion of all or part of the rectum from the anatomical position of the rectum and protruding from the anus in all its layers (1). Although the actual frequency of the disease, which is accepted as a sliding hernia in various sources, is not known in the society, it is known that it is more common in the male population at an early age, while it is more common in women in adulthood. The generally accepted theory in its etiology is that an anatomical defect becomes evident for various predisposing reasons and causes the disease. Although so many surgical techniques have been described, there are still disagreements about the most ideal intervention method, due to the low frequency of the disease and the lack of large prospective randomized studies to prove the superiority of the surgical techniques applied to each other. Laparoscopy entered surgical practice about 20 years ago and has become widespread rapidly due to its advantages such as less pain, shorter hospital stay, earlier return to work, and better cosmetics. Laparoscopic procedures, which combine the functional results of open abdominal procedures with the advantages of minimally invasive surgery such as less pain, better cosmetics, and low perioperative morbidity, are recommended as the first treatment option in the treatment of RP (2). For this reason, the best surgical treatment for RP is still unknown and efforts to find an ideal intervention are still ongoing. However, the common goal of all described surgical interventions is to correct the deteriorated anatomical structure and to restore defecation mechanisms (3). In this study, it was aimed to investigate the abdominal and perineal approaches together with postoperative early and late results in our patients who underwent surgical treatment for RP.

\section{Öz}

benzerdir. Cerrahın deneyimine ve hastane olanaklarına göre cerrahi yöntemi seçmek gerekir.

Anahtar kelimeler: Abdominal ve perineal cerrahi, notaras operasyonu, rektal prolapsus

\section{Materials and Methods}

The records of 39 patients who underwent surgical treatment with the diagnosis of RP between January 2010 and January 2020 in the Department of General Surgery, Dicle University Faculty of Medicine were evaluated retrospectively. Ethics committee approval for the study was obtained from Dicle University Faculty of Medicine, Health Sciences NonInterventional Clinical Research Ethics Committee, with the decision dated 07.05.2020 and numbered 149. Patients' age, gender, symptoms at admission, duration of admission to the hospital, co-morbidities, physical examination findings, surgical methods applied, length of hospital stay, early and late postoperative complications, recurrence and mortality rates were recorded. Relapse cases, patients with inflammatory bowel disease and concomitant malignancy who had previously undergone surgical treatment with the diagnosis of RP were excluded from the study. Based on the physical examination findings of the patients, RP was classified according to the grading system made by Altemeier et al. (4) (Table 1). Concomitant diseases of the patients, including cardiovascular diseases (ischemic heart disease and/or heart failure, hypertension), respiratory diseases (chronic obstructive pulmonary disease and/or asthma) and diabetes, were considered. Due to technical shortcomings, anal manometry, electromyelography and endoanal ultrasonography,can not be analyzed, and preoperative and postoperative patient satisfaction was evaluated using the Boutsis-Ellis criteria (Table 2) (5).

All patients underwent bowel cleansing in the preoperative period and additional pathologies were investigated by performing rectosigmoidoscopy. The patients were

Table 1. Rating of rectal prolapse (4)

\section{Stage 1: Mucosal prolapse}

Stage 2: Intussusception of the rectum or rectosigmoid junction

Stage 3: True rectal prolapse 
Table 2. Boutsis-Ellis criteria (5)

Stage 1: Normal control, rarely wetting with mucus

Stage 2: Gas control disorder, frequent mucus

Stage 3a: Frequent loss of control, wetting with feces in situations such as diarrhea

Stage 3b: Wetting with feces loss of total control

administered $2^{\text {nd }}$ generation cephalosporin 1 gr/iv 30 minutes before the operation for prophylaxis. All surgical methods were performed under elective conditions, under general or spinal anesthesia, with abdominal or perineal approaches. The choice of the surgical method was carried out according to the experience and preference of the surgeon, taking into account the patient's age, general condition, accompanying pathologies and complaints. All patients were given a laxative agent and a high-fibrin diet postoperatively. Patients were followed up at 1, 6 and 12 months postoperatively, and after that, an annual checkup was recommended. The patients who did not come for the control were contacted by phone and questioned in terms of constipation, incontinence and the presence of recurrence.

\section{Abdominal Surgical Procedures}

Applied surgical procedures included posterior rectopexy (with and without prosthetic material) and rectopexy with sigmoid colon resection. In all abdominal methods, the rectum is completely liberated from the posterior wall of the proximal sacrum to the tip of the coccyx in the pelvis, and below the pouch of Douglas or cul-de-sac on the anterior and lateral walls. The lateral ligaments were cut in some cases and preserved in others. Posterior rectopexy was defined as the liberated rectum being pulled upwards from the pelvic floor and fixed to the presacral fascia of the sacrum. In the Ripstein technique, poly-propylene prosthetic material prepared in the form of a rectangle to encircle the rectum was fixed to the presacral fascia with non-absorbable sutures $5 \mathrm{~cm}$ below the promontorium (6). In the Notaras technique, the prosthetic material used was detected in the sacrum so that it covered the rectum 1/3-2/3 posteriorly (7). In patients with a long sigmoid colon, after mobilizing the rectum without cutting the lateral ligaments, posterior rectopexy (Goldberg-Frykman technique) was performed with sigmoid colon resection and colorectal anastomosis (8). In perineal proctosigmoidectomy (Altemeier technique), the rectum was cut in full thickness 2-3 $\mathrm{cm}$ proximal to the linea dentata in patients in whom the rectum protruded at least $5 \mathrm{~cm}$. After the rectosigmoid colon was freed by opening the peritoneum, a colorectal anastomosis was performed by cutting from the proximal end of the overhanging part (9). In the Delorme technique, the rectal mucosa was excised in the form of a $3-4 \mathrm{~cm}$ ring from $1 \mathrm{~cm}$ proximal to the linea dentata, and an end-to-end anastomosis of the remaining mucosa was performed (10).

In the laparoscopic rectopexy technique, After the sigmoid colon meso was retracted laterally, the peritoneum was opened from the promontorium to the inferior mesenteric vessels and dissection was started from medial to lateral. Meanwhile, the hypogastic plexus, left ureter, and left gonadal vessels were visualized and the lateral ligaments were mobilized using Ligasure Atlas ${ }^{\circledR}$ (Vessel Sealing System, Tyco Healthcare Co., Ltd. USA). The sigmoid resection procedure was completed with an endoscopic linear stapler (Endo GIA 60, Tyco Healthcare Co, USA or Echelon, Ethicon Endosurgery, Cincinati, USA) to preserve the splenic flexion and lateral connections of the descending colon. The suprapubic trocar area (approximately $4 \mathrm{~cm}$ ) was expanded and the sigmoid colon was removed from the abdomen. After intracorporeal anastomosis was performed with a transanally advanced circular stapler, it was fixed from the perirectal tissue $3 \mathrm{~cm}$ distal to the anastomosis to the presacral fascia at the level of the rectum promontorium.

\section{Statistical Analysis}

SPSS (Statistical Package for Social Sciences) Windows 11.5 program was used for statistical analysis in the evaluation of the findings obtained in the study. Descriptive statistics were used to evaluate the data. Quantitative data were expressed as median. The chi-square test was used to compare qualitative data. The Mann-Whitney U test was employed to compare non-parametric quantitative data. $\mathrm{p}<0.05$ was considered statistically significant.

\section{Results}

Demographic and characteristic findings of the patients are shown in Table 3. The most common complaints were gas control, defecation problems, and often wetting with mucus. On physical examination, stage $1 \mathrm{RP}$ was found in $12.8 \%$ of the patients, and full-thickness prolapse was found in the other patients. The mean age of 39 patients included in the study was 36 (14-88) years. Surgery was performed with an abdominal and perineal approach in $53.8 \%$ of the patients, while laparoscopy was performed in $46.2 \%$. The most frequently used abdominal surgical technique was Notaras (35.8\%). The most common perineal approach technique was Altemeier (5.1\%). Complications developed in the early postoperative period in $10.4 \%$ of the patients. When patients who underwent 
abdominal open surgery and patients who underwent laparoscopic surgery were compared, the length of hospital stay was statistically significant $(\mathrm{p}=0.021)$, but there was no significant difference when compared with other variables. When surgical approaches were compared, demographic and characteristic findings were similar except that the mean age was higher in open abdominal surgery. Although postoperative early and late complications were more common in patients who had open abdominal surgery, no statistical difference was found. Surgical treatments applied to patients with RP were classified (Table 4). No recurrence was observed in either group (Table 5). The median hospital stay was 5 days (2-19) and the follow-up period was 13 months (9-19). Postoperative mortality did not occur in any of the patients. Hospital stay was significantly shorter in patients who underwent laparoscopic surgery. There was no statistical difference in terms of early postoperative

\begin{tabular}{|c|c|}
\hline Age* (year) & $36(14-88)$ \\
\hline \multicolumn{2}{|l|}{ Gender } \\
\hline Male, n (\%) & $25(64.1)$ \\
\hline Female, n (\%) & $14(35.9)$ \\
\hline \multicolumn{2}{|l|}{ Previous surgical history $\mathrm{n}(\%)$} \\
\hline Abdominal surgery & $2(5.2)$ \\
\hline Lateral internal sphincterectomy & $1(2.6)$ \\
\hline \multicolumn{2}{|l|}{ Application complaints (Boutsis-Ellis criteria) } \\
\hline Stage $1, \mathrm{n}(\%)$ & $31(79.4)$ \\
\hline Stage $2, \mathrm{n}(\%)$ & $4(10.3)$ \\
\hline Stage $3 a, n(\%)$ & $3(7.7)$ \\
\hline Stage $3 b, n(\%)$ & $1(2.6)$ \\
\hline \multicolumn{2}{|l|}{ Physical examination findings } \\
\hline Full-thickness, n (\%) & $34(87.2)$ \\
\hline Mucosal, n (\%) & $5(12.8)$ \\
\hline \multicolumn{2}{|l|}{ Additional diseases in the patient $* * \mathbf{n}(\%)$} \\
\hline Chronic diseases & $10(25.7)$ \\
\hline Hypertension & $5(12.8)$ \\
\hline Cancer & $3(7.7)$ \\
\hline Psychiatric diseases & $4(10.3)$ \\
\hline Hemorrhoids-fissure-other prolapse & $5(12.8)$ \\
\hline \multicolumn{2}{|l|}{ Complications n (\%) } \\
\hline One year later, re-operation from inguinal hernia & $1(2.6)$ \\
\hline Operate hemorrhoids after 6 months & $1(2.6)$ \\
\hline latrogenic left ureter injury & $1(2.6)$ \\
\hline Postop abdominal abscess and ileus & $1(2.6)$ \\
\hline Hospital stay, day* & $5(2-19)$ \\
\hline Follow-up time, month* & $13(9-19)$ \\
\hline
\end{tabular}

*Data are given as median (minimum-maximum), **There are more than one disease in some patients complications and recurrence. No postoperative mortality or complication requiring reexploration was observed. Patients were followed for a median of 19 months. Continence was achieved in all patients, except for $3(0.7 \%)$ patients who had gas control disorders in late control examinations and no recurrence was observed. When the abdominal and perineal approaches applied to the patients were compared, demographic and characteristic findings were found to be similar, except that the mean age was more advanced in perineal approaches. Abdominal approaches were performed under general anesthesia, while perineal approaches were often performed under regional anesthesia. The hospital stay was shorter in perineal approaches. Although early postoperative complications were seen only in patients who underwent abdominal surgery, no statistical difference was found. No recurrence was observed in either group.

\section{Discussion}

Numerous methods have been proposed for the treatment of RP, which can be done by perineal or abdominal route. Other factors such as the age and gender of the patient, the presence of constipation and incontinence, and the general condition of the patient, as well as the experience

\begin{tabular}{|c|c|}
\hline \multicolumn{2}{|l|}{ Surgical methods } \\
\hline Open surgery, n (\%) & $21(53.8)$ \\
\hline Laparoscopy, n (\%) & $18(46.2)$ \\
\hline \multicolumn{2}{|l|}{ Surgical methods applied } \\
\hline Notaras, n (\%) & $14(35.8)$ \\
\hline Retropexy n (\%) & $15(38.5)$ \\
\hline Ribstein, n (\%) & $5(12.8)$ \\
\hline Goldberg-Frykman, n (\%) & $3(7.7)$ \\
\hline Altemeier n (\%) & $2(5.1)$ \\
\hline
\end{tabular}

Table 5. Comparison of open abdominal and laparoscopic surgery patients due to rectal prolapse

\begin{tabular}{llll} 
& $\begin{array}{l}\text { Open } \\
\text { abdominal } \\
\text { surgery }\end{array}$ & $\begin{array}{l}\text { Laparoscopic } \\
\text { abdominal } \\
\text { surgery }\end{array}$ & $\mathbf{p}$ \\
\hline $\begin{array}{l}\text { Age } \\
\text { Gender } \mathbf{n}(\%)\end{array}$ & $39(16-88)$ & $28(14-68)$ & 0.422 \\
Male & $15(33.3)$ & $11(38.9)$ & 0.718 \\
Female & $7(66.7)$ & $6(61.1)$ & \\
$\begin{array}{l}\text { Previous surgical } \\
\text { operation, } \mathbf{n}(\%)\end{array}$ & & & \\
No & 19 & 17 & 0.643 \\
Yes & 2 & 1 & \\
\hline
\end{tabular}


of the surgeon in this regard, are also effective in the choice of method (11). Since perineal procedures have a higher recurrence rate, they are generally preferred in elderly patients with comorbid factors or in men who do not accept the risk of sexual dysfunction, even if it is less (11). In the laparoscopic treatment of RP, rectopexy, resection, resection-rectopexy procedures were applied. In all studies, laparoscopic procedures were found to be as safe and effective as conventional surgery $(2,12)$. The hospital stay is shorter and the operation time is longer in laparoscopy (13). Abdominal rectopexy, resection and resection-rectopexy procedures were performed and the last one was found to be superior in terms of functional results and recurrence when compared with other methods $(14,15)$. The advantages of rectopexy alone are short hospital stay, early rehabilitation, excellent cosmetics, and low cost. Resection-rectopexy is a more invasive procedure compared to rectopexy alone. In addition to anastomotic leakage and pelvic sepsis, an incision of approximately $4 \mathrm{~cm}$ is required to remove the resected sigmoid colon. Abdominal incision problems such as infection, hematoma, and hernia formation may occur in this incision. On the other hand, functional results are better when resection is performed. Many issues are still being discussed, especially the limits of pelvic dissection in abdominal surgeries, whether or not to cut the lateral ligaments, whether or not to protect the superior rectal vessels in patients who have undergone resection, and how fixation should be done (patch, suture, tack). Speakman et al. (16) suggested that cutting the lateral ligaments caused constipation, and in other studies, with this idea, the lateral ligaments were not cut in order to protect the middle rectal vessels and accompanying nerves (17-19).

The clinical picture in RP depends on the type and degree of prolapse. Patients may have one or more of the complaints of tenesmus, urgent need to defecate, rectal bleeding, mucous discharge and incontinence (15). In the study of Çalıskan et al. (6), which included 68 patients, in the preoperative evaluation performed according to the Boutsis-Ellis criteria, stage 2 incontinence was found in 29 of the patients, stage $3 \mathrm{a}$ in 11 , stage $3 \mathrm{~b}$ in 7 , and stage $3 \mathrm{a}$ and 16 in 2 after surgical treatment. They reported that stage 2 incontinence complaints continued during her period. In our study, 31 (79.4\%) of the preoperative patients had stage 1, 4 (10.3\%) stage 2, 3 (7.7\%) stage 3a and 1 (2.6\%) stage $3 \mathrm{~b}$ incontinence. Complete continence was achieved in all patients, except for $2(0.5 \%)$ patients whose stage 2 incontinence continued after surgical treatment. It has been reported that $70-90 \%$ of patients with RP have full thickness and $10 \%$ have mucosal prolapse (20). In the preoperative physical examination, $87.2 \%$ of our patients had full-thickness prolapse and $12.8 \%$ had mucosal prolapse. In the early period in the treatment of RP, although it has been reported that different conservative approaches such as prevention of straining during defecation, regulation of defecation method and time, elimination of constipation, perineal relaxing exercises, electronic stimulation, sclerosant injection, band ligation and infrared coagulation may be beneficial, many of these patients need an additional surgical method (21). While all abdominal approaches were performed under general anesthesia, $80 \%$ of perineal approaches were performed under regional anesthesia. Early postoperative complications were seen in $10.4 \%$ of our patients and all of them were in patients who underwent abdominal method. No early postoperative complications were observed in patients who underwent perineal method. The hospital stay was shorter in perineal approaches compared to abdominal approaches, since it is a less invasive procedure. High fiber diet and oral laxative use were recommended in our patient who underwent the Ripstein method because of the persistence of postoperative constipation. Postoperative incontinence complaint persisted at a rate of $0.5 \%$, one patient from each group.

Mortality rates after RP surgery are reported to be between $0 \%$ and $2 \%$ (22). In our study, no mortality was observed in any patient who underwent surgical treatment.

\section{Study Limitations}

The limitation of our study is that the surgical technique chosen was determined by the experience of the patient and the surgeon, and we think that prospective, multicenter studies with large patient series are needed.

\section{Conclusion}

Considering the risk factors in terms of surgical treatment, patient's findings and the surgeon's experience, the results of the abdominal or perineal approaches to be preferred in patients who underwent both methods are similar, and RP can be treated surgically with low complications. However, laparoscopic resection-suture rectopexy is a safe and effective method in the treatment of RP. The method has the general advantages of minimally invasive surgery such as shorter hospital stay, better cosmetics, and less morbidity. Perineal approaches may be preferred in highrisk patients in terms of surgical treatment due to low complications and early positive results. In comparison of the long-term results of abdominal and perineal 
approaches, studies with larger patient series and long follow-up periods are needed.

\section{Ethics}

Ethics Committee Approval: The records of 39 patients who underwent surgical treatment with the diagnosis of RP between January 2010 and January 2020 in the Department of General Surgery, Dicle University Faculty of Medicine were evaluated retrospectively. Ethics committee approval for the study was obtained from Dicle University Faculty of Medicine, Health Sciences Non-Interventional Clinical Research Ethics Committee, with the decision dated 07.05.2020 and numbered 149.

Informed Consent: Patients were not required to give informed consent to the study because the analysis used anonymous clinical data that were obtained after each patient agreed to treatment by written consent.

Peer-review: Externally and internally peer-reviewed.

\section{Authorship Contributions}

Concept: Ö.B., F.V.A., G.Y., A.O., Desing: Ö.B., F.V.A., G.Y., Data Collection or Processing: Ö.B., F.V.A., G.Y., Analysis or Interpretation: Ö.B., H.B., G.Y., Drafting Manuscript: Ö.B., H.B., G.Y., Critical Revision of Manuscript: Ö.B., H.B., F.V.A., Final Approval and Accountability: Ö.B., H.B., G.Y., Supervision: H.B., Ö.B., A.O.

Conflict of Interest: No conflict of interest was declared by the authors.

Financial Disclosure: The authors declared that this study received no financial support.

\section{References}

1. Ozgonul A, Uzunkoy A, Sogut O, Yalcin M. Three-year experience with rectal prolapse patients. J Clin Med Res 2010;2(4):177-179.

2. Kariv Y, Delaney CP, Casillas S, Hammel J, Nocero J, Bast J, et al. Long term outcome after laparoscopic and open surgery for rectal prolapse: a case-control study. Surg Endosc 2006;20(1):35-42.

3. Duthie GS, Bartolo DC. Abdominal rectopexy for rectal prolapse: a comparision of techniques. Br J Surg 1992(2);79:107-113.

4. Altemeier WA, Culbertson WR, Schowegerdt C, Hunt S. Nineteen years experience with the one stage perineal repair of rectal prolapse. Ann Surg 1971;173(6):993-1006.

5. Boutsis C, Ellis H. The Ivalon sponge wrap operation for rectal prolapse. Dis Colon Rectum 1974;17(1):21-37.
6. Çalıskan C, Korkut AM, Fırat Ö, Akgün E, Osmanoğlu H. Rectal prolapse experience: 68 cases in 27 years. Ege Journal of Medicine 2008;47(1):29-34.

7. Karulf RE, Madoff RD, Goldberg SM. Rectal prolapse. Curr Probl Surg 2001;38(10):771-832.

8. Frykman HM. Abdominal proctopexy and primary sigmoid resection for rectal procidentia. Am J Surg 1955;90(5):780-789.

9. Gordon PH. In: Gordon PH, Nivatvongs S, eds. Principles and Practice of Surgery for the Colon, Rectum, and Anus, 2nd ed. St. Louis, MO: Quality Medical Publishing Inc, 1999:575-717.

10. Longo A. Treatment of hemorrhoid disease by reduction of mucosa and hemorrhoidal prolapse with a circular suturing device: a new procedure. In: Proceedings of 6th World Congress of Endoscopic Surgery, Rome, Italy, 1998:777-784.

11. Akbari RP, Read TE. Laparoscopic rectal surgery: rectal cancer, pelvic pouch surgery, and rectal prolapse. Surg Clin North Am 2006;86(4):899-814.

12. Purkayastha S, Tekkis $\mathrm{P}$, Athanasiou T, Aziz O, Paraskevas $\mathrm{P}$, Ziprin P, et al. A comparison of open vs. laparoscopic abdominal rectopexy for full-thickness rectal prolapse: a meta-analysis. Dis Colon Rectum 2005;48(10):1930-1940.

13. Solomon MJ, Young CJ, Eyers AA, Roberts RA. Randomized clinical trial of laparoscopic versus open abdominal rectopexy for rectal prolapse. Br J Surg 2002;89(1):35-39.

14. Mckee RF, Lauder JC, Poon FW, Aitchison MA, Finlay IG. A prospective randomized study of abdominal rectopexy with and without sigmoidectomy in rectal prolapse. Surg Gynecol Obstet 1992;174(2):145-148.

15. Duthie GS, Bartolo DC. Abdominal rectopexy for rectal prolapse: a comparison of techniques. Br J Surg 1992;79(2):107-113.

16. Speakman CT, Madden MV, Nicholls RJ, Kamm MA. Lateral ligaman division during rectopexy causes constipation but prevents recurrence: results of a prospective randomized study. $\mathrm{Br}$ J Surg 1991;78(12):1431-1433.

17. Lechaux D, Trebuchet G, Siproudhis L, Campion JP. Laparoscopic rectopexy for full thickness rectal prolapse. a single institution retrospective study evaluating surgical outcome. Surg Endosc 2005;19(4):514-518.

18. Madiba TE, Baig MK, Wexner SD. Surgical management of rectal prolapse. Arch Surg 2005;140(1):63-73.

19. Bruch HP, Herold A, Schiedeck T, Schwandner O. Laparoscopic surgery for rectal prolapse and outlet obstruction. Dis Colon Rectum 1999;42(9):1189-95.

20. McKee RF, Lauder JC, Poon FW. A prospective randomized study of abdominal rectopexy with and without sigmoidectomy in rectal prolapse. Surg Gynecol Obstet 1992;174(2):145-148.

21. Atkinson KG, Taylor DC. Wells procedure for complete rectal prolapse: a 10 year experience. Dis Colon Rectum 1984;27(2):9698.

22. Cuthbertson AM, Smith JA. An abdominal repair for complete rectal prolapse. ANZ J Surg 1988;58(6):499-503. 